DOI 10.17150/978-5-7253-3001-4.44

B. А. ПАРХОМОВ

УДК 947

П.В. КУРГУЗОВ

ББК 63.3(2)613-3,633(2)

\title{
ИЗБИРАТЕЛЬНОЕ ПРАВО, КАК ОРУДИЕ КЛАССОВОЙ БОРЬБЫ
}

На основе архивных данных и отчетов избирательных комиссий различного уровня, рассматривается проблема лишения избирательных прав советских граждан во время избирательных кампаний 
1926-1928 гг. в городской Совет г. Троицкосавска. Показано, что избирательное право является одним из способов борьбы с гражданами, носителями буржуазной идеологии, и создания нового советского общества.

Ключевые слова: избирательное право, лишение прав, лишенцы, восстановление субъективного избирательного права.

V.A. PARKHOMOV

P. V. KURGUZOV

\section{SUFFRAGE AS AN INSTRUMENT OF THE CLASS STRUGGLE}

The problem of deprivation of election rights of citizens is investigated on based archival documents and reports of election commissions different levels during elelctions companies 1926-1928 years in the Troiskosavsk city council. It is shown that election rights can use as kind of struggle against with own citizens which have another ideology and creation of new Soviet society.

Keywords: election law, election rights, deprivation of election rights, recovery of rights.

Избирательное право в субъективном смысле, принадлежит каждому отдельному гражданину, достигшему 18-летнего возраста, и использование права зависит от его воли. Основным источником избирательного права, фиксирующим его главные принципы, является конституция государства. Это право обеспечивает субъектам (гражданам) участвовать в управлении государством и является «высшим непосредственным выражением власти народа» [1], путем участия в формировании выборных органов государства, органов местного самоуправления и референдумах. В мировой практике применяются ограничения избирательных прав граждан с криминальным прошлым. Лишение избирательных прав лиц, имевших (имеющих) судимость или находящихся в местах лишения свободы применяется и в российском избирательном законодательстве.

В настоящее время выборы, определяемые ст. 3 и 32 Конституции РФ, являются демократическими [1]. Под демократичностью подразумевается свобода использования права в зависимости от воли гражданина. О демократичности выборов (только по участию в них граждан) в современной России можно судить по отчетам избирательных комиссий о явке избирателей на выборы президента страны и в Государственную думу. Так в 2012 г. на выборах президента РФ явка составила 65,34 \%, а на выборах 18 марта 2018 г. - 67,47 \% [2]. Явка на выборы в Государственную думу разных созывов соответственно составила: 47,62 \% в 2003 г., 63,78 \% в 2007 г., 60,21 \% в 2011 г. и 47,88 \% в 2016 г. [2]. Pe- 
зультаты явки на выборы показывают действительное волеизъявление российских граждан свободное от каких-либо ограничений. Но всегда ли так было в истории России?

В 1918-1936 гг. избирательное право в РСФСР регулировалось Конституцией, принятой 10 июля 1918 г, в четвертом разделе которой даны нормы активного и пассивного избирательного права [3]. Прежде всего, следует отметить, что 13 глава Конституции содержит подробный перечень граждан, имеющих и не имеющих такого права, но только к середине 1920-х гг. в стране в целом, и в регионах, в частности, окончательно оформляются процессуальные нормы лишения и восстановления в избирательных правах. Лишение избирательных прав в Советской России, как один из методов классовой борьбы, существовало с момента принятия первой советской Конституции 1918 г. и до вступления в силу «сталинской» Конституции 1936 г.

Мы не ставим перед собой глобальную задачу составить представление об основных социально-демографических параметрах городских и сельских «лишенцев» Бурят-Монгольской республики. Наша задача рассмотреть на примере конкретных граждан практику применения 13 главы Конституции в г. Троицкосавске Бурят-Монгольской АССР на выборах 1928 г. Для ясности дальнейшего изложения процитируем положения пункта 65 главы 13: «Не избирают и не могут быть избранными, хотя бы они входили в одну из нижеперечисленных категорий: были;

а) лица, прибегающие к наемному труду с целью извлечения при-

б) лица, живущие на нетрудовой доход, как-то: проценты с капитала, доходы с предприятий, поступления с имущества и т.п.;

в) частные торговцы, торговые и коммерческие посредники;

г) монахи и духовные служители церквей и религиозных культов;

д) служащие и агенты бывшей полиции, особого корпуса жандармов и охранных отделений, а также члены царствовавшего в России дома;

е) лица, признанные в установленном порядке душевнобольными или умалишенными, а равно лица, состоящие под опекой;

ж) лица, осужденные за корыстные и порочащие преступления на срок, установленный законом или судебным приговором.

Конституция РСФСР 1925 г. содержала аналогичный список лиц, лишенных избирательных прав, в ст. 69» [4].

Количество лишенцев было значительным и варьировало от региона к региону. Так, в выборной кампании 1927 г. только в Западном регионе РСФСР количество лишенцев возросло до 3038 тыс. чел. с 1040 тыс. человек в кампанию 1925-1926 гг. [6, с. 65].

В РСФСР было лишено избирательных прав 2433390 чел., или 4,5 \% взрослого населения. При этом численность лишенцев в сельской местности составила 1706025 чел. (3,9%) против 1390747 чел. (3,3%) 
в избирательную кампанию 1926-1927 гг. Процент лишенцев увеличился практически повсеместно.

Всего в СССР количество лишенцев возросло на 700 тыс. чел. В итоге по стране было лишено избирательных прав 3716 тыс. чел. (4,9 \% взрослого населения). В сельской местности число лишенцев составило 4,1\% [7].

Статьей 15 «Инструкции о выборах городских и сельских Советов и о созыве Съезда Советов» от 26 ноября 1926 г.» [10] указывались группы населения, подлежащие лишению избирательных прав и был установлен порядок восстановления в избирательных правах «при условии, если эти лица в настоящее время занимаются производительным и общественно-полезным трудом и доказали лояльность по отношению к Советской власти». Лишенцы имели возможность обжаловать решение избирательных комиссий в недельный срок со дня опубликования или ознакомления со списком лишенных избирательных прав.

Приводимые далее документы показывают, что некоторые граждане, лишенные избирательных прав решением городских избирательных комиссий, обращались с заявлениями в вышестоящие комиссии и даже получали положительные решения последних.

В Троицкосавске лишили избирательных прав не только граждан, подпадающих под признаки норм конституционного списка, но и всех бывших офицеров царской армии как участвующих в гражданской войне на стороне белых, так и не участвующих в ней, а также жен офицеров. Постановления о лишении избирательных прав принимались на основании списков, представляемых городским судом, административным отделом аймачного исполкома либо по данным партийных ячеек. Последний список особенно примечателен количеством граждан, включенных в него, и описанием рода их занятий. Приводим впечатляющий фррагмент из последнего списка [11, л. 17, 17 об]. «Поп Малышев, ул. Соснина. Служитель религ. культа. Жена попа Малышева, ул. Соснина. Доход от домовладения. Тетя Груня (выделено нами), ул. Серова. Торгует пивом, квасом, пельменями и пользуется наемным трудом.

Рычкова по Набережной улице. Подрядчица погр. отряда».

Подробнее рассмотрим список лишенных права выбора в Советы 1928 г., представленный в избирком [11, л. 21], решение республиканской избирательной комиссии о лишении избирательного права И.Н. Бароцци де Эльс [11, л. 9] и заявление супруги бывшего атамана 3 военного отдела Забайкальского казачьего войска о восстановление ее избирательного права [11, л. 2, 3].

«Резолюция: в избирком

Список бывших белых офицеров, проживающих в городе Троицкосавске

1. Коробин Сергей Сергеевич — чиновник военного времени 
2. Лизунов Николай Устинович — поручик армии Семенова

3. Лесанобский Казимир Викентьевич - прапорщик старой армии

4. Кантер Олег Павлович — прапорщик армии Семенова

5. Коковин Леонид Михайлович - юнкер старой армии

6. Кокорин Пантелеймон Семенович - юнкер Колчака

7. Ижболдин Дмитрий Александрович — чиновник военного времени

8. Зарубин Иннокентий Дмитриевич - поручик Семенова

9. Буйновсий Михаил Николаевич - подпоручик Колчака

10. Бобров Александр Семенович - прапорщик Семенова

11. Бурин Петр Петрович - подполковник старой армии

12. Никипоренко Константин Семенович - чиновник военного времени и Семенова

13. Баранович Евгений Владимирович - штабс-капитан Семенова

14. Халтурин Семен Александрович - прапорщик Семенова

15. Правоверов Александр Васильевич - прапорщик Колчака

16. Якимов Георгий Дмитриевич — чиновник военного времени и Сем

17. Лозакович Сергей Дмитриевич - то же

18. Анисимов Иннокентий Николаевич - подпоручик Семенова

19. Чирков Михаил Николаевич - то же

20. Демкин Георгий Степанович - чиновник военного времени и Сем

21. Самойлов Михаил Васильевич - то же

22. Оверин Иван Афранасьевич - то же (карандаш -умер)

23. Буйновский Николай Юлианович - полковник Колчака

24. Бородцы дэ Эльс Иван Николаевич - полковник старой армии

25. Николаев Павел Васильевич - подпоручик Семенова

26. Берг Василий Германович - прапорщик Колчака

27. Лисецкий Николай Анисимович - подпоручик Семенова

28. Чирков Иосиф - подпоручик Семенова

29. Далее список бывших полицейских - 2 пристава и 4 полицейских» $[11$, л. 3].

В списке содержится 6 фамилий офицеров разного звания и военных чиновников старой армии, которые не участвовали в гражданской войне на стороне Белой Армии, но все равно, занесенных в список «лишенцев». Среди фрамилий офицеров, не служивших в Белой Армии, выделим номер 24 - Бародци дэ Эльс Иван Николаевич (в написании фрамилии ошибки, которые встречаются в архивных документах и далее, поэтому дадим правильное написание - Бароцци де Эльс).

Приведем его биографию из журнала «Разведчик», издаваемого до 1917 г. в Санкт-Петербурге.

«Бароцци де Эльс Иван Николаевич. 02.09.1866-1932?

Православный. Образование получил в Иркутской военной прогимназии. В службу вступил 28.07.1883. Окончил Иркутское пехотное юнкерское училище. В офицеры произведен в 4-й Восточно-Сибирский линейный ба- 
тальон. Подпоручик (ст. 13.12.1886), поручик (ст. 13.12.1890), подъесаул (приказ 1893, ст. 22.11.1893; за отличие), есаул (пр. 1899, ст. 06.05.1899; за отличия). Ст. адъютант 3 военного отдела ЗабКВ (30.10.2000-18.01.2007). Помощник атамана 1 военного отдела ЗабКВ (18.01.2007-20.07.2013). Войсковой старшина (пр. 1908, ст. 26.02.1908; за отличие). Атаман 3 военного отдела ЗабКВ (с 08.07.2013). Полковник (пр.1913 ст. 05.10.1913; за отличие). На 01.03.1914 г. и 01.08.1916 г. в том же чине и должности.

Награды: ордена Св. Станислава 2-й степени (1907), Св. Анны 2-й ст. (1911), Св. Владимира 4-й ст. (ВП 13.06.1915) [5].

Как видно, Иван Николаевич имел заслуги перед российским государством и честно исполнял свой воинский долг в старой армии. По своему статусу он не подпадал ни под один из пунктов гл. 65 ст. 13 Конституции РСФСР.

У атамана было три сына, которые служили в дореволюционной армии и участвовали в Великой войне. Один из них Николай Иванович посмертно был награжден Георгиевским крестом 4 степени. Поэтому причина лишения Ивана Николаевича избирательных прав, на наш взгляд, кроется в общем неправовом и классовом подходе лиц, принимавших решение о лишении. Об этом свидетельствует документ Центральной избирательной комиссии БМАССР, проверявшей постановление городской избирательной комиссии [10].

«Г. Троицкосавск

Заседания Троицкосавской Гор. Избир. комиссии.

Состоявш. 8 января 1931 г.

Слушали: Отношение Центр. Избиркома от 9 ноября 1931 г. за № 109-б, о проверке правильности лишения избирательных прав Бороцци-Де-Эльс.

Постановили: Проверив весь материал по делу лишения избирательных прав Бороцци-Де_эльс, нашли: что согласно ст. 15 п.л, как бывшему казачьему атаману Отдела отказать, т.к. таковой не проявил за все это время лояльности к Соввласти и не имеющего трудстажа за все время революции.

Подлинный за надлежащими подписями.

С подлинным верно. Секретарь Попова.

Центризбиркому БМАССР.

На № ОЖд-1019 от 23.12.1929 г.

Наш Вх. № 294 от 31.12. с.г.

При сем представляется материал по делу об избирательных правах гр. Бароцци-Де-Эльс Ивана Николаевича, как-то: заявление, выписка из протокола Аймачной избир. комиссии. Кроме этого гр-ну Бороцци-Де-Эльс была вручена выписка из протокола Центральной Избир. комиссии БМАССР, в которой также в восстановлении его в избират. правах отказано. 
Приложение: Упомянутое.

Зам. Предгорсовета Жаркой.

Секретарь Копылевич.

Гр. Бароцце-де-Эльс Иван Николаевич в настоящее время живет на иждивении сына Бароцце-де-Эльс Понтелеймона Ивановича, служащего в Троицкосавском Потреб. Обществе в качестве счетовода.

Предгорсовета Лихонин.

Секретарь Попова».

Вызывает удивление и уважение решение супруги Николая Ивановича обжаловать решение избирательной комиссии о лишении ее избирательных прав. Заявление в комиссию написано очень грамотно с точки зрения знания прав и русского языка [11, л. 23].

«В избир. комиссию Троицкос. Горсовета от гражданки Антонины Клавдиевны Бароцци-Де-Эльс.

Заявление.

В опубликованном Комиссией списке лиц лишенных права голоса, при выборах в горсовет, помещена я с указанием причины права лишения меня голоса, как жены бывшего атамана отдела, между тем в п. И ст. 12 инструкции о выборах в Советы утвержденной Президиумом ЦИК ССР от 28 сентября 1926 г. и действительной при настоящих выборах точно указано, что, члены семей лиц лишенных избирательных прав, не лишаются избирательных прав, я же от мужа материально не завишу, так как он инвалид, не имеющий своих средств. И мы оба находимся на иждивении сына, почему я до настоящего г. ни разу не лишалась права голоса.

Ввиду приведенного лишения меня права голоса, как не соответствующего закону Советского правительства, считаю не справедливым и прошу о восстановлении меня в законных гражданских правах.

О последующем распоряжении прошу объявить мне по месту жительства: Троицкосавск, Исполкомская улица, дом № 1.

22 декабря 1928 г.

А. Бароцци-Де-Эльс.»

Городская избирательная комиссия рассмотрела заявление и приняла положительное решение [11, л. 24].

«Г. Троицкосавск

Троицкосавская избирательная комиссия.

Личное дело по лишению избирательных прав Бароцци-Де-Эльс Антонины Клавдеевны.

Нач. 1928 г. окончено 1928 г.

Заявление гр. Бароцци-Де-Эльс Антонины Клавдиевны.

Выписка из протокола № 3 очередного заседания Троицкос. избир. комисси.

24 декабря 1928 г. 
Слушали: 6. Ходатайство гр-ки Бороцци-Де-Эльс А.К. о восстановлении ее в избирательных правах. Назимов.

Ввиду того, что гр-ка Бароцци-де-Эльс материально от мужа Бароцци-Де-Эльс Ивана Николаевича - бывшего Атамана отдела не зависит, а находится на иждевении сына служащего в кооперации-признать возможным восстановить гр-ку Бароцци-Де-Эльс Антонину Клавдиевну в избирательных правах» [11, л. 24].

Таким образом, анализируя представленные материалы, можно видеть, что лишение избирательных прав в отдельно взятом городе, как и в стране в целом, осуществлялось по принципу происхождения и социальной принадлежности, без учета биографий, заслуг и действительного положения лишенцев. Лишение избирательных прав было одним из главных инструментов, применявшихся советской властью для борьбы с лицами, которые были носителями старой, буржуазной идеологии и были направлены на изменения общественной структуры страны в годы проведения политики «ликвидации кулачества как класса» [8, с. 88]. Однако, как свидетельствуют статистические данные, приведенные выше, процент лишения избирательных прав сельского населения в целом по СССР составил 4,1 \%, а по РСФСР - 3,9 \%, т.е. «лишенцами» были городские жители - бывшие офицеры, чиновники и лица, занимающиеся мелким производством. Списки для лишения прав, подаваемые комячейками, были прообразом и подготовкой к «красному террору» 1937 года.

\section{Список использованной литературы и источников}

1. Конституция РФ от 12.12.1993 г. - М. : Проспект, 1993. - 47 с.

2. Отчеты избирательных комиссий о явке на выборы президента РФ и в Государственную думу РФ за 2003, 2007, 2011, 2016 г. [Электронный ресурс]. — Peжим доступа : https://www.rbc.ru/politics/08/12/2003/, http://cikrf.ru/activity/ relevant/ detail/29886/, https://www.interfax.ru/russia/528903, http://cikrf.ru/activity/ docs/ postanovleniya/26549/, https://tass.ru/info/4844712

3. Конституция РСФСР от 10 июня 1918 г. [Электронный ресурс] // Исторический факультет МГУ : сайт. - Режим доступа : http://www.hist.msu.ru/ER/

4. Etext/cnst1918.htm.

5. Конституция РСФСР 1925 г. [Электронный ресурс] // Сайт Конституции Российской Федерации. - Режим доступа : http://constitution.garant. ru/history/ ussr-rsfsr/1925/red_1925/

6. ВП по военному ведомству // Разведчик. - 2015. — № 1297. - 15 сент.

7. Валуев Д. В. Лишенцы в системе социальных отношений (1918-1936 гг.) (на материалах западного региона РСФСР) : дис. ... канд. ист. наук / Д. В. Валуев. - Смоленск, 2003.

8. Выборы в Советы и состав органов власти в СССР [Электронный ресурс]. - М., 1931. - Режим доступа :https://archive.org/details/vybory_ sovet_ sostav_organov

9. Ергина Н. М. Лишение избирательных прав в кампанию выборов в Советы 1928-1929 гг. в национальных регионах Поволжья (на примере сельских местно- 
стей Мордовии и Татарстана) / Н. М. Ергина // Известия Алтайского государственного университета. - 2011. - Вып. 4. - Т. 1. - С. 84-89.

10. Итоги выборов в Советы РСФСР в 1929 г. - Вып. 1 : Выборы в сельские, волостные и районные органы власти : стат. сб. - М. : Изд-во «Власть советов» при Президиуме ВЦИК, 1930.

11. Инструкция о выборах городских и сельских Советов и о созыве съездов Советов. Утв. Президиумом ВЦИК 4 нояб. 1926 г. [Электронный ресурс] // Красноярское общеаство МЕМОРИАЛ. - Режим доступа : http://www.memorial.krsk.ru/ DOKUMENT/USSR/301020.htm

12. Национальный Архив Республики Бурятии. - Ф. Р-726. - Оп. 1. Д. 163 (Троицкосавская избирательная комиссия. Список лиц, лишенных избирательных прав бывших белых офицеров, торговцев. За 1928 год).

\section{Информация об авторах}

Пархомов Владимир Александрович — доктор фризико-математических наук, профессор кафедры информатики и кибернетики, Байкальский государственный университет, 664003, Иркутск, ул. Ленина, 11; e-mail: pekines_41@mail.ru

Кургузов Павел Владимирович - соискатель кафредры философии, истории и культурологии, Восточно-Сибирский государственный университет технологий и управления, 670013, г. Улан-Удэ, ул. Ключевская, 40B, стр. 1; e-mail: bpnf1968@bk.ru

\section{Authors}

Vladimir A. Parkhomov - Doctor of Physical and Mathematical Sciences, Professor, Department of Informatics and Cybernetics, Baikal State University, 11 Lenin St., 664003, Irkutsk, Russia; e-mail: pekines_41@mail.ru

Pavel V. Kurguzov - PhD Student, Department of Philosophy, History and Cultural Studies, East Siberia State University of Technology and Management, 40B bld 1 Klyuchevskaya St., 670013, Ulan-Ude, Russia; e-mail: bpnf1968@bk.ru 